Klara SULIČ

Ana KUČAN

\title{
Analiza potreb po javnih zelenih površinah v Grosupljem
}

\begin{abstract}
Za Grosuplje kot mlado mesto in primestno naselje velike Ljubljane je $v$ zadnjih dveh desetletjih značilno veliko povečanje stanovanjske in poslovno-obrtne gradnje, s čimer se veča tudi število možnih uporabnikov odprtega prostora. Urejanje tega razvoju poselitve do nedavnega ni uspešno sledilo in zelene površine mesta v procesu urbanizacije niso bile obravnavane celostno ali enakovredno drugim rabam prostora. Na podlagi teh izhodišč je bilo zastavljeno osnovno vprašanje, kakšne so danes potrebe po tipih in količini urejenih zelenih površin v Grosupljem. Predpostavljeno je bilo, da v mestu tako ustrezno urejenih površin, ki bi učinkovito služile potrebam uporabnikov, primanjkuje, porajal pa se je tudi dvom o dostopnosti in javnem značaju obstoječih zelenih površin, kar je lahko precejšnja ovira za uporabnika. Da bi preverili te domneve in izhodišča, je bila med prebivalci izvedena krajša anketna raziskava, sočasno pa opravljena tudi analiza prostora. Glavni ugotovitvi sta bili dve. Problem mestnih zelenih površin in odprtih prostorov se bolj kot na količino nanaša na kakovost ureditve ter vsebino teh prostorov. Potrebe po urejenih zelenih površinah izražajo tako prebivalci enodružinskih hiš kot večstanovanjskih objektov. Na podlagi ugotovitev so bile podane splošne usmeritve za urejanje zelenih površin v Grosupljem in tudi usmeritve, ki so lahko v pomoč pri oblikovanju podobe mesta.
\end{abstract}

KLJUČNE BESEDE: urejene javne zelene površine, analiza potreb, podoba mesta

\section{Uvod}

Obravnavano mesto je eno izmed tistih slovenskih urbanih naselij in mest, ki jim lahko kot osnovno pozitivno lastnost pripišemo dobro umeščenost $\mathrm{v}$ prostor. Uporabniki odprtega prostora namreč iz katerega koli predela mesta $\mathrm{v}$ nekaj minutah in skoraj neposredno dostopajo do naravne in kulturne krajine v okolici, ki jim predstavljata obsežne površine za rekreacijo. Tudi sicer je mesto precej zeleno. Znotraj poselitvenega območja ima veliko prostih zelenih površin, $\mathrm{k}$ zeleni podobi pa močno prispeva tudi prevladujoči tip zazidave, to je prostostoječa enodružinska hiša z vrtom. Tak tip gradnje pomeni, da je gostota uporabnikov odprtega prostora $v$ Grosupljem
A huge increase in residential and business-commercial construction has characterised Grosuplje, a young town and suburban settlement of the greater Ljubljana area, over the last two decades, thereby increasing the number of possible users of its open space. The arrangement of this settlement development to date has not been successfully followed and urban green areas undergoing the urbanisation process were not treated fully or equivalently to other spatial utilisation. Based on these departure points, a basic question has arisen: what types and quantities of planned green areas are needed in Grosuplje today? It was assumed that such planned areas which would effectively serve the needs of users were lacking in the town, yet doubt regarding accessibility and the public nature of existing green areas has arisen, which could pose a considerable obstacle to users. In order to verify these assumptions and departure points, a short research survey was carried out with the residents, with a spatial analysis performed simultaneously. There were two key findings. The problem of urban green areas and open spaces is more about the quality of the arrangement and content of these spaces rather than the quantity. The need for planned green areas was expressed by the residents of both single homes and multi-storey dwellings. General guidelines for planning green areas in Grosuplje as well as guidelines which could aid in designing the town's appearance were given based on these findings.

KEY WORDS: planned public green areas, needs analysis, urban appearance

razmeroma nizka in da ima velik delež prebivalstva za preživljanje prostega časa na prostem na voljo zasebne vrtove. Kakšna je torej $\mathrm{v}$ takem mestu potreba po zelenih površinah javnega značaja in kako pomembne so za mestno strukturo? Predpostavljeno je bilo, da se potrebe prebivalcev enodružinskih hiš in večstanovanjskih objektov sicer razlikujejo, vendar obe skupini izražata potrebo po urejenih javnih zelenih površinah. Enako je bilo predpostavljeno, da bo razlike o dojemanju mestnega prostora in zelenih površin mogoče opaziti med priseljenimi in domačini. Glede na ugotovitve prostorske analize je bila potreba po površinah javnega značaja $\mathrm{v}$ preteklosti nedvomno manj izražena ali slabo prepoznana, kar je tudi eno izmed mnogih pojasnil, zakaj njihovo 
urejanje ni vedno uspešno sledilo naglemu razvoju gradnje ter ni bilo obravnavano celostno in enakovredno drugim rabam prostora. Javnih zelenih površin se tudi ni ustrezno vzdrževalo in se jih, čeprav so že bile potrjene $\mathrm{v}$ zazidalnih načrtih ali predvidene $\mathrm{v}$ preteklih družbenih planih, ni uresničilo. Teža takih odločitev je toliko večja, saj gre za majhen poselitveni prostor, ki ga lahko sprememba, izguba ali neuresničitev posamezne vsebine bistveno osiromaši. Poleg tega mesto, ki se hitro razvija, ni nikoli gradilo svoje prepoznavne podobe, zato si mora to še ustvariti. Ustrezno obravnavane in načrtovane zelene površine jo lahko pomagajo soustvarjati.

Namen raziskave je bil s pomočjo ankete ugotoviti odnos prebivalcev mesta do obstoječega stanja urejenih zelenih površin in odprtega prostora ter tudi ugotoviti njihove potrebe po tipih in količini urejenih zelenih površin. $Z$ analizo prostora mesta se je preverjalo stanje zelenih površin, in sicer $z$ vidika urejenosti, vsebine, razporeditve $\mathrm{v}$ mestu, členitve prostora, podobe mesta in $\mathrm{z}$ vidika uporabnikov. Slednji se je nanašal na vse predhodne vidike in je dodatno upošteval še oddaljenost zelenih površin od uporabnikov. Glede na splošne prostorske značilnosti Grosupljega, ki je kot rečeno precej zeleno mesto, je bil poudarek raziskave na urejenih in javnih zelenih površinah, to je oblikovanih in vzdrževanih prostorih mestne krajine, ki so v javni rabi in dostopni vsem uporabnikom. Namen je poudariti drugačnost teh prostorov od zelenih površin na mestnem obrobju. Te so sicer pomembno rekreacijsko območje, vendar so za nekatere uporabnike slabo dostopne ali zaradi oddaljenosti, neprimerne podlage, ki ovira gibanje, ovir v prostoru ali drugih značilnosti. Dejavnosti, ki potekajo na teh površinah, in način druženja so drugačni od tistih na zelenih površinah v mestu. Cilj raziskave je bil na podlagi ugotovitev analitičnega dela podati splošne smernice urejanja zelenih in odprtih površin Grosupljega. Pri tem naj bi se obstoječe površine po potrebi količinsko dopolnilo, predvsem pa vse zelene površine in odprte prostore povezalo $\mathrm{v}$ celoto, $\mathrm{ki}$ bo uporabna za prebivalce, v razvoju enakovredna vsem ostalim rabam prostora in pomemben element podobe mesta.

\section{Teoretična izhodišča za raziskavo}

Mestne zelene površine so tista sestavina prostora, ki povečuje možnosti za srečevanje in druženje prebivalcev. Ti niso homogena skupina, temveč govorimo o različnih starostnih in uporabniških skupinah, ki imajo tudi zelo raznovrstne potrebe, različna izražanja in različne prioritete zadovoljevanja posameznih potreb. Nekatere izmed teh potreb so vsem ljudem skupne in se nanašajo na osnovne človeške potrebe, kot so sprostitev, udobje, zaposlitev, raziskovanje ipd. (Polič, 1996), medtem ko so druge potrebe posebne, značilne za posamezne skupine in kategorije prebivalcev. Nanašajo se lahko na starost, izobrazbo, socialni status, poklic, zdravstveno stanje ipd., po predstavljeni raziskavi celo glede na to, ali nekdo živi v samostojni hiši ali $v$ večstanovanjskem objektu. V prostoru obstajajo tudi skupine uporabnikov, ki so pogosto spregledane in za katere je značilno, da potrebujejo za zadovoljevanje svojih potreb urejene zelene površine v bližnji okolici (Marcus in Francis, 1998). To so ljudje z manjšo gibalno sposobnostjo (ostareli, invalidi, ipd.), predšolski in šolski otroci ter najstniki. B. Goličnik in I. Šuklje Erjavec (2006) opozarjata, da specifičnost potreb običajno ne pomeni tudi potrebe po posebnih prostorih, ampak jih je $\mathrm{v}$ načrtovanje treba vključiti v celotnem prostoru ter ga tako narediti dostopnega in uporabnega za vse. Celovitost mestnih zelenih površin se nanaša tudi na sistem različnih vsebin in razporejenost zelenih površin $\mathrm{v}$ prostoru mesta, ki morajo biti od uporabnikov primerno oddaljene, s stališča posamezne zelene površine pa dostopnost in uporabnost za vse nakazujeta elemente, ki določajo uspešen javni odprti prostor. Del tega so tudi mestne zelene površine. V literaturi (Francis, 2003; Goličnik, 2008; Polič 2000) je kot ena ključnih sestavin soustvarjanja uspešnih prostorov prepoznana prisotnost uporabnikov, pri čemer bodo na raznovrstnost uporabniških skupin vplivali raznovrstnost dejavnosti, programa, urbane opreme, členitev prostora, kot tudi urejenost in vzdrževanost površin. B. Goličnik (2006) v analizi trgov in parkov ugotavlja, da so javni mestni prostori uspešni in vitalni, kadar so hkratna prizorišča treh značilnih vrst dejavnosti: dolgotrajnejših aktivnih in pasivnih dejavnosti ter dejavnosti v prehodu čez prostor. Če povzamemo, so javni odprti prostori in zelene površine uspešni oziroma ustrezni, kadar so odzivni na potrebe uporabnikov. To pomeni, da te potrebe uspešno zadovoljujejo, in kot ugotavlja Polič (2000), spodbujajo pozitivno socialno interakcijo. Ljudje se tako v prostoru tudi zadržujejo in ga uporabljajo. Ob vseh navedenih potencialih in priložnostih, ki jih lahko nudi prostor, so nazadnje uporabniki tisti, ki ustvarjajo učinkovita okolja, prostore dejanskih rab ter uresničenih in izrabljenih priložnosti (Goličnik in Šuklje Erjavec, 2006).

Ustrezno in hkrati estetsko urejene mestne zelene površine, ki so odzivne na potrebe uporabnikov, ne prispevajo le $\mathrm{k}$ višji kakovosti bivalnega okolja, temveč tudi $\mathrm{k}$ dobri in prepoznavni podobi mesta. $\mathrm{Ta}$ je sicer preplet urejanja/kompozicije odprtega 
prostora ter tudi arhitekturnega oblikovanja in urbanizma. Podoba, ki jo določa tudi sistem mestnih zelenih površin, je lahko razvidna že na načrtovalni ravni. Kaže se v strukturi sistema, to je $\mathrm{v}$ sestavi, razporeditvi, hierarhiji in medsebojnih odnosih odprtih površin ter $\mathrm{v}$ njihovem odnosu do grajenega prostora ali v strukturi, ki izhaja iz naravnih značilnosti prostora. V ožjem merilu je treba podobo mesta razumeti tudi $\mathrm{z}$ vidika zaznavanja in doživljanja prostora, skozi katerega se gibljemo. Zelene površine $\mathrm{k}$ temu prispevajo s svojo velikostjo in vidno prepoznavnostjo ter $\mathrm{z}$ medsebojnimi povezavami in $\mathrm{s}$ povezavami $\mathrm{z}$ mestnim obrobjem ter grajenim tkivom. Druge sestavine te podobe so tudi posamezne podrobnosti $v$ načinu oblikovanja z zelenjem, urejanju in vzdrževanju posameznih pomembnih prostorov $\mathrm{v}$ mestu. K. Dimitrovska Andrews in K. Repič Vogelnik (1995) naštejeta poleg osrednjih mestnih parkovnih površin tudi ureditve pred objekti javnega značaja, drevorede, glavne mestne vpadnice, glavne povezovalne poti za pešce in kolesarje, obrežja vodotokov, vstope $\mathrm{v}$ mesto in mestni rob, poglede in razglede na ključne prepoznavne elemente mesta ipd. Če je poselitveni prostor mesta majhen, je pomen takih ureditev še močnejši, urejanje odprtega prostora pa mora biti prilagojeno posebnim problemom in potencialom mesta.

\section{Analiza prostora}

\subsection{Način dela}

Za razumevanje urbanističnega razvoja naravnih in kulturnih značilnosti Grosupljega je analiza prostora $\mathrm{v}$ začetku vključevala pregled pisnih virov in kartografskega gradiva ${ }^{[1]}$. V nadaljevanju je največje delo obsegal terenski ogled mesta in posebej analiza zelenih površin skupaj z odprtimi prostori. Izhajajoč iz teoretičnih izhodišč so bila določena podrobnejša merila za opazovanje ter popis vsebine, ureditve in uporabe zelenih površin:

- površina je oblikovani prostor mestne krajine;

- določena je vsebina, ki ima poudarjeno družbenopovezovalno vlogo;

- površina je v javni rabi;

- mesta za sedenje (število in razporeditev);

- prisotnost urbane opreme (klopi, koši, luči, vodni motivi, skulpture ipd.;

- točke zbiranja (število in razporeditev);

- preglednost območja;

- dostopnost (fizična in vidna);

- število uporabnikov;

- način uporabe prostora (prehod čez prostor ali zadrževanje $\mathrm{v}$ prostoru).
Ogled je bil v pomladanskem času ponovljen dvakrat, in sicer v popoldanskem času med tednom ter $\mathrm{v}$ dopoldanskem času konec tedna. Zabeleženo je bilo tudi, katera starostna skupina uporabnikov se na površini zadržuje ali jo prečka: otroci, mladina, ljudje, srednje starosti, ali starejši. Na podlagi zbranih podatkov se je kasneje določilo, katere površine $\mathrm{v}$ Grosupljem so zares urejene javne zelene površine in kakšno je njihovo stanje. Izbor je bil nato uporabljen pri analizi razporeditve in dostopnosti posameznih tipov zelenih površin - površin vsakodnevne rabe, športnih površin in otroških igrišč. Obravnavane so bile tudi (poljavne) zelene površine stanovanjskih območij, kjer je bil popis opravljen na podlagi zgornjih meril, ki določajo ureditev in uporabo površine. Površine zasebnega značaja niso bile vključene v podrobno analizo.

\subsection{Ugotovitve}

\subsubsection{Zelene površine stanovanjskih območij}

Med stanovanjskimi območji v Grosupljem prevladujejo z 89 \% prostostoječe enodružinske hiše z vrtovi. Območja takega tipa pozidave so v primerjavi s celotnim območjem mesta in v primerjavi z območji večstanovanjskih objektov razmeroma velika, sklenjena, drugo drugemu zelo podobna in nečlenjena. Edini javni prostor in »otroško igrišče« teh območij je bila nekoč ulica, ki je danes vse prometnejša. Namesto, da bi ljudi zbliževala, zmanjšuje družbene stike med njimi. Območja enodružinskih hiš praviloma tudi nimajo poljavnih zelenih površin, na katerih bi se različne skupine uporabnikov družile in zadrževale. Stanovalci lahko na vrtovih zadovoljijo veliko potreb po preživljanju prostega časa na prostem, predvsem pa gre tu za potrebo po zasebnosti. Po drugi strani zasebni vrt ne omogoča naključnih srečanj in družabnih dejavnosti s širšim krogom ljudi ter tudi ne nekaterih drugih izbirnih in bolj posebnih dejavnosti, na primer različnih oblik rekreacije. Iz tega razmišljanja lahko sklepamo, da prebivalci te vrste stanovanjskih območij prav tako kot prebivalci večstanovanjskih objektov v svoji okolici oziroma $\mathrm{v}$ mestu potrebujejo poljavne in javne zelene površine. Tudi Mlinar (1972; v: Doležal, 1991) je $z$ anketami ugotovil, da prebivalci enodružinskih hiš in večstanovanjskih objektov javne parkovne površine obiskujejo enako pogosto. Glede na ugotovljene prostorske značilnosti območij enodružinske gradnje v Grosupljem lahko rečemo, da bi urejanje poljavnih zelenih površin izboljšalo strukturo in zanimivost ožjega kot tudi širšega mestnega prostora. Prostor bi tako namreč členili, vanj vnesli vsebinske in oblikovne poudarke ter posameznemu območju dodali nov svojstven element. 
Poljavne zelene površine ob večstanovanjskih objektih so v splošnem razmeroma kakovostno urejene. Vsebujejo površine za igro otrok, vrtičke ter ureditve za druženje in zbiranje ostalih stanovalcev, pri čemer so za druženje mladine morda najmanj ustrezne. Od prometnih površin so navadno ločene, vendar se kljub temu $\mathrm{v}$ zadnjih letih s povečanjem prometa kot problem pojavlja zasedanje zelenic in celo otroških igrišč s parkiranimi avtomobili. Glede na ugotovitve opazovanja je razloge za to med drugim mogoče iskati $v$ pomanjkanju števila parkirnih mest $\mathrm{v}$ primerjavi s povečanjem motoriziranega prometa in $\mathrm{v}$ nepripravljenosti stanovalcev, da parkirajo svoja vozila na bolj oddaljenih prostih javnih parkirnih površinah $\mathrm{v}$ mestu. V Grosupljem je za zelene površine in predvsem otroška igrišča ob večstanovanjskih objektih značilno, da kljub svojemu poljavnemu značaju in namenu služijo tudi širši okolici in stanovalcem sosednjih stanovanjskih območij, to je stanovanjskih območij enodružinskih hiš. Vloga teh površin $\mathrm{v}$ mestu je torej širša, vendar to še ne pomeni, da mesto ne potrebuje tudi javnih zelenih površin (in otroških igrišč).

\subsubsection{Urejene javne zelene površine}

Urejene javne zelene površine so del oblikovanih prostorov mestne krajine. Ob pregledu urejenih zelenih površin na ravni mesta se zastavita vprašanji, katere površine $\mathrm{v}$ Grosupljem so zares javne in dostopne vsem uporabnikom ter kako raznolika in pestra je vsebina posamezne zelene površine ali površin v mestu na splošno. Ugotovitve so naslednje:

1. Urejene zelene površine v Grosupljem so površine ob objektih javnega značaja (šole, vrtci, dom starejših občanov, občinska stavba in banka), športna igrišča (nogometno in teniško), pokopališča in dve manjši tlakovani, vendar parkovno oblikovani ureditvi.
Nogometno in teniško igrišče sta posebni površini, na katerih je dostop omejen s plačilom oziroma je površina namenjena članom nogometnega kluba. Ureditev pred domom starejših občanov je bolj ko ne namenjena prebivalcem ustanove, saj z okolico ni povezana in ima reprezentativni značaj, tako kot ga imata zelenica pred občinsko stavbo in ureditev pred banko. Zadnja morda najbolj ustreza dejavnostim raznolikih skupin uporabnikov. Čeprav je površina te ureditve majhna, vsebuje številne elemente, ki so zanimivi za uporabnike: ploščad, stopnice, pot, zelenico, spomenik, klopi in zasaditev. Vse skupaj ustvarja razgiban in členjen prostor, ki se poleg vsega nahaja ob najpomembnejši pešpovezavi v mestu, to je med osrednjim delom in železniško postajo. Skupine uporabnikov, ki so bile opažene $\mathrm{v}$ prostoru, so starejši in drugi odrasli, mame $\mathrm{z}$ otroki, rolkarji in najstniki. To je pomemben podatek, če vemo, da večina zelenih površin $\mathrm{v}$ mestu ni urejena na način, ki bi vzpodbujal druženje mladih. Športne površine ob šolah, kjer se mladi pogosto zadržujejo, so namreč prostori aktivne udeležbe, in kot bo zapisano kasneje, na njih primanjkuje točk za zbiranje in ureditev, ki bi vzpodbujale pasivno udeležbo. Kljub temu so bile površine ob šolah in vrtcih od nekdaj glavno gibalo urejenih mestnih zelenih površin in tudi družbenih interakcij v Grosupljem. Prvi šoli in vrtca s pripadajočimi zunanjimi površinami so bili zgrajeni že zelo zgodaj, potreb po dodatnih športnih in otroških igriščih zunaj okvira teh ustanov pa ni bilo. Tako urejene površine za šport, rekreacijo in oddih imajo dostop časovno omejen na popoldanski čas in konec tedna, ko ni pouka. S tega vidika jih ne moremo šteti kot prave javne površine. Prave javne zelene površine ostanejo tako pokopališča in manjši parkovni ureditvi.

2. Grosuplje ima torej veliko zelenih površin, ki pa imajo svoje pomanjkljivosti. Začetno domnevo, da $\mathrm{v}$ mestu primanjkuje ustrezno urejenih površin, ki
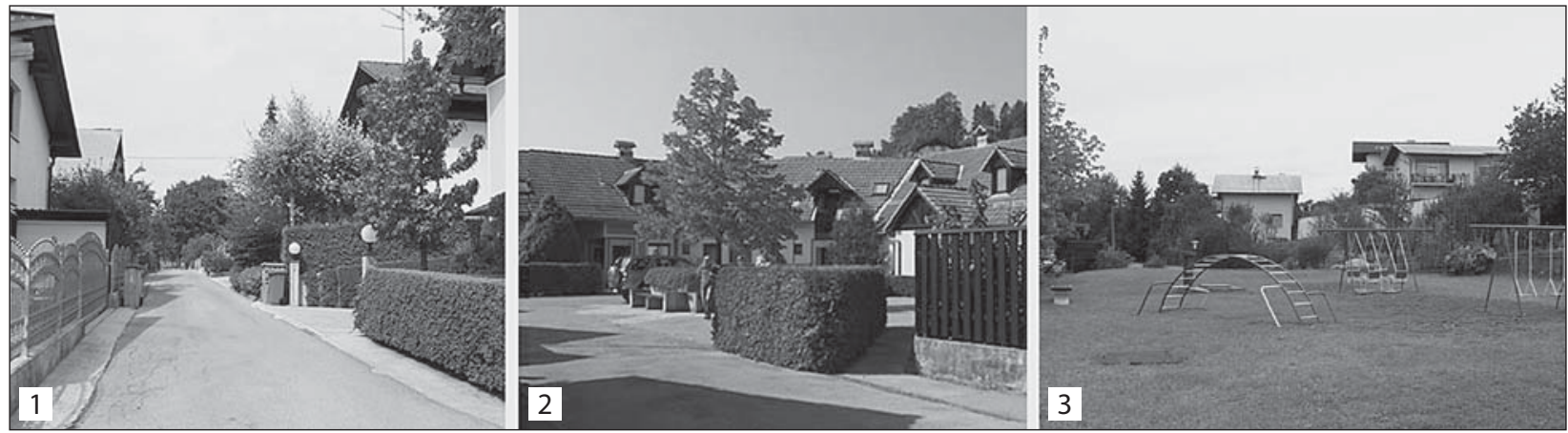

Slika 1: 1 - odprti prostor stanovanjskih območij enodružinskih hiš, ki ne vsebuje poljavnih zelenih površin; 2 - edini primer stanovanjskega območja enodružinskih hiš, ki te površine vsebuje (Dvori, avtor urbanistične zasnove prof. Alojzij Drašler); 3 - poljavne zelene površine ob večstanovanjskih objektih (foto: Klara Sulič). 
bi učinkovito služile potrebam uporabnikov, lahko delno potrdimo. V zadnjih dveh desetletjih se $s$ hitro rastjo mesta in širitvijo stanovanjskih površin (enodružinske in večstanovanjske gradnje) spreminja razmerje v razporeditvi urejenih javnih zelenih površin. Analize oddaljenosti od uporabnikov in prečkanj najbolj obremenjenih prometnic so pokazale, da površin vsakodnevne rabe oziroma poljavnih površin $\mathrm{v}$ obliki manjših ureditev z zelenicami, urbano opremo in otroškimi igrali primanjkuje $\mathrm{v}$ stanovanjskih območjih na robu mesta. Športna igrišča so potrebna v stanovanjskem območju Sončni dvori, ki ga od mesta loči železnica.

Iz analize po merilih za določanje urejenih javnih zelenih površin lahko ugotovimo tudi, da se problemi teh površin ne nanašajo le na količino, temveč predvsem na slabše vzdrževanje (propadanje urbane opreme, praznjenje košev ipd.),

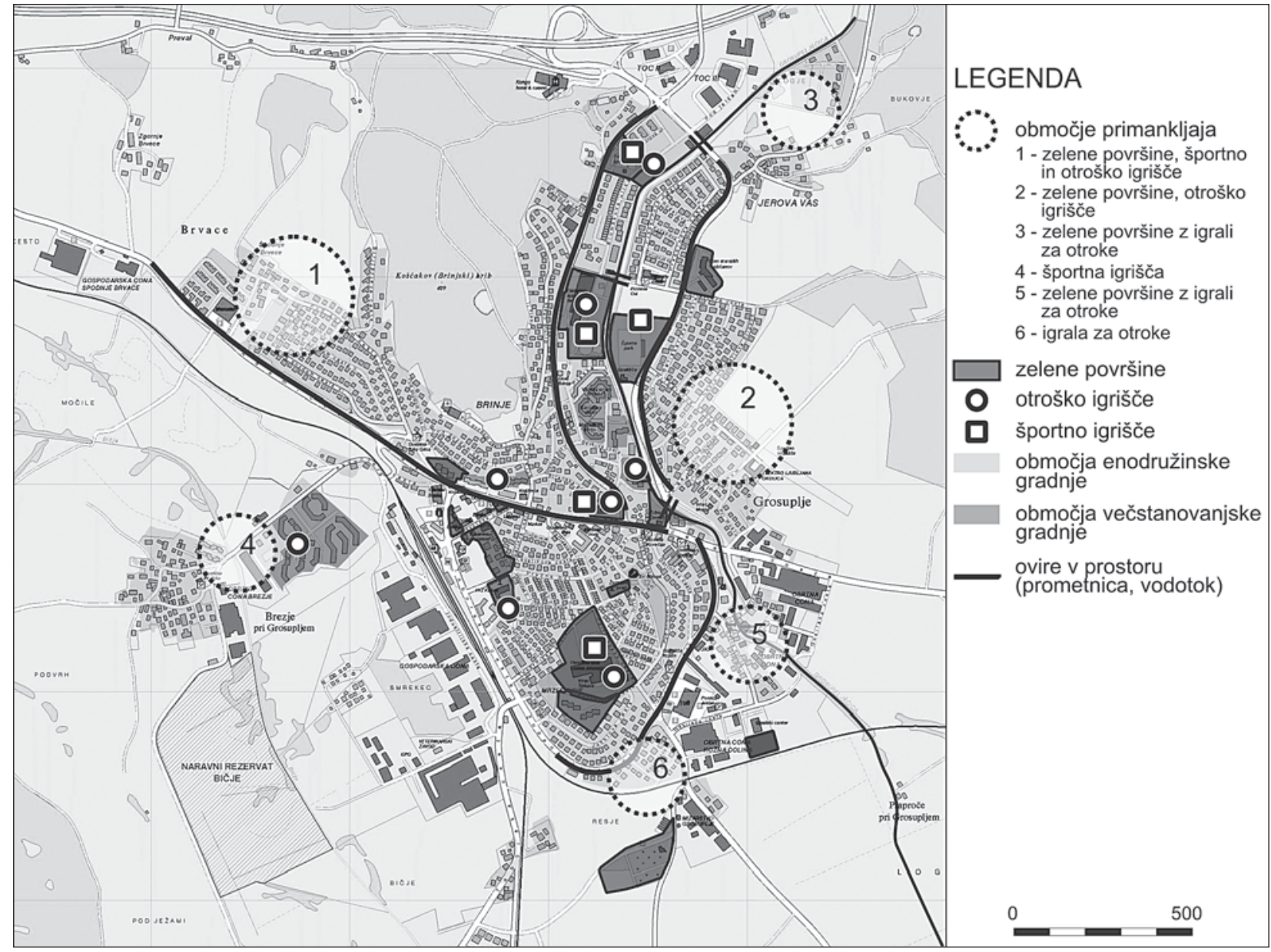

Slika 2: Območja primanjkljaja urejenih javnih in poljavnih zelenih površin so bila pridobljena na podlagi analize ovir v prostoru, razporeditve in oddaljenosti zelenih površin od uporabnikov.
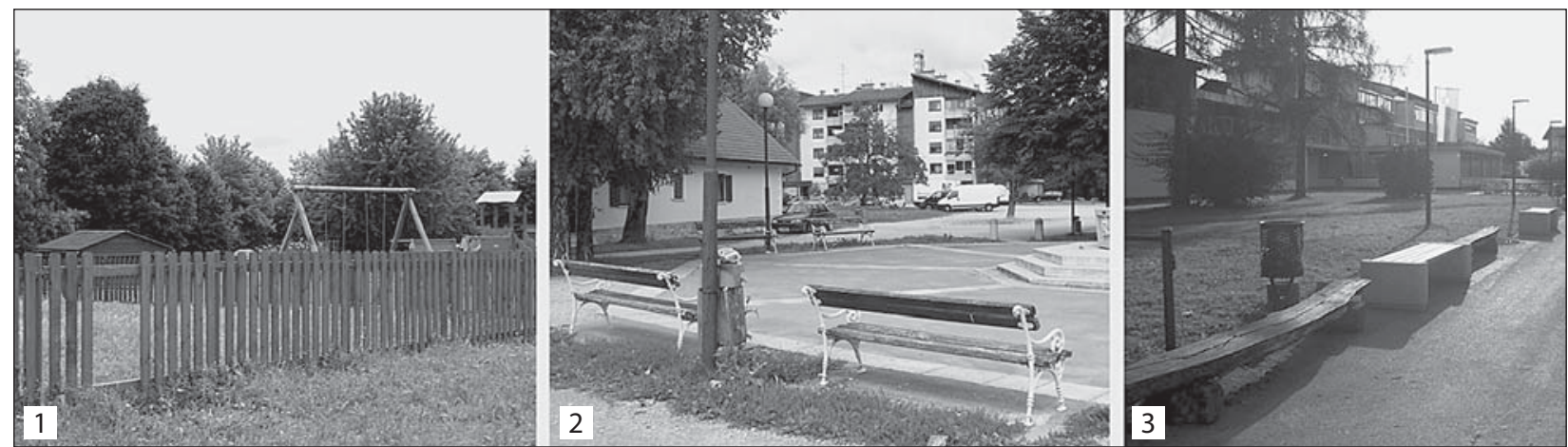

Slika 3: 1 - športne površine ob šolah in otroška igrišča ob vrtcih so ograjeni in javno dostopni le v določenem času; 2 - primer slabšega vzdrževanja površin in urbane opreme na osrednjih zelenih površinah, kot so šole in tržnica (foto: Klara Sulič). 
pomanjkljivo opremo (predvsem pomanjkanje klopi) in manj ustrezno oblikovanje (pomanjkanje podprostorov, členitev) obstoječih površin.

3. Površine ob šolah in vrtcih so največje osrednje zelene površine $\mathrm{v}$ mestu, $\mathrm{z}$ igrišči, velikimi travnatimi površinami, s potmi in z bogato zasaditvijo. Prostor je zelo odprt in estetsko privlačen. Govorimo o tistih pozitivnih oblikovnih in strukturnih značilnostih prostora, ki bi lahko izražale zanimivo in za uporabnike privlačno zeleno površino. Opazovanja kažejo, da je dogajanje na teh površinah vezano na dolgotrajno aktivno udeležbo $\mathrm{v}$ športu in je skoncentrirano v okolici igrišč, medtem ko preostali prostor ni izkoriščen. B. Goličnik (2006) poleg treh značilnih vrst dejavnosti, ki naj bi potekale na uspešnih in vitalnih prostorih poudarja tudi ustrezno členitev prostora, ki te različne oblike dejavnosti vzpodbuja. Na obravnavanih površinah ob šolah dejavnosti $v$ prehodu čez prostor obstajajo, omogočanje pasivnih (posedanje na klopeh, ležanje v travi, opazovanje ipd.) pa je prezrto. Deloma zaradi količinskega pomanjkanja in neustrezne postavitve urbane opreme ter deloma zaradi strukture posameznega območja. Glede na prostorske značilnosti celotnega območja mesta - pomanjkanje raznolikosti in poudarkov v enakomernem poselitvenem območju - so velike in prostorne travnate površine izrednega pomena, vendar so z vidika uporabnikov najbrž manj privlačne za pasivno rabo. Ocenjeno je, da bi ustrezna členitev z manjšimi gručami drevja ali grmovnic in predvsem ustreznejša urbana oprema možnosti za pasivno rabo prostora povečala. Uporabniki so $\mathrm{v}$ takem primeru manj izpostavljeni ostalim udeležencem in so lahko $\mathrm{v}$ dogajanje vključeni bolj pasivno.

4. Parkovni ureditvi, ki sta bili v analizi opredeljeni kot javni, sta danes predvsem priložnosti, s pomočjo katerih mora mesto $\mathrm{v}$ prihodnje, $\mathrm{v}$ povezavi z drugimi zelenimi površinami (glavni drevored, zelene površine ob potoku Grosupeljščica), načrtovati vsebinsko in oblikovno kakovostne mestne zelene površine. Obe ureditvi sta izrazito prehodni območji, eno od njiju - tržnica - tudi prostor zbiranja. Oblikovno in programsko bi morali obe površini omogočati več izbirnih in družabnih dejavnosti ter hkrati zadovoljiti nujne dejavnosti ob prehodu čez prostor.

\subsubsection{Zelene površine v vlogi sooblikovanja podobe mesta}

V članku so izpostavljene le najočitnejše pomanjkljivosti podobe Grosupljega, ki so bile prepoznane $\mathrm{z}$ analizo prostora: vstopi in območje centra. Oboje pomembno vpliva na doživljanje mesta, posebej zato, ker so razdalje $v$ njem majhne in od enega
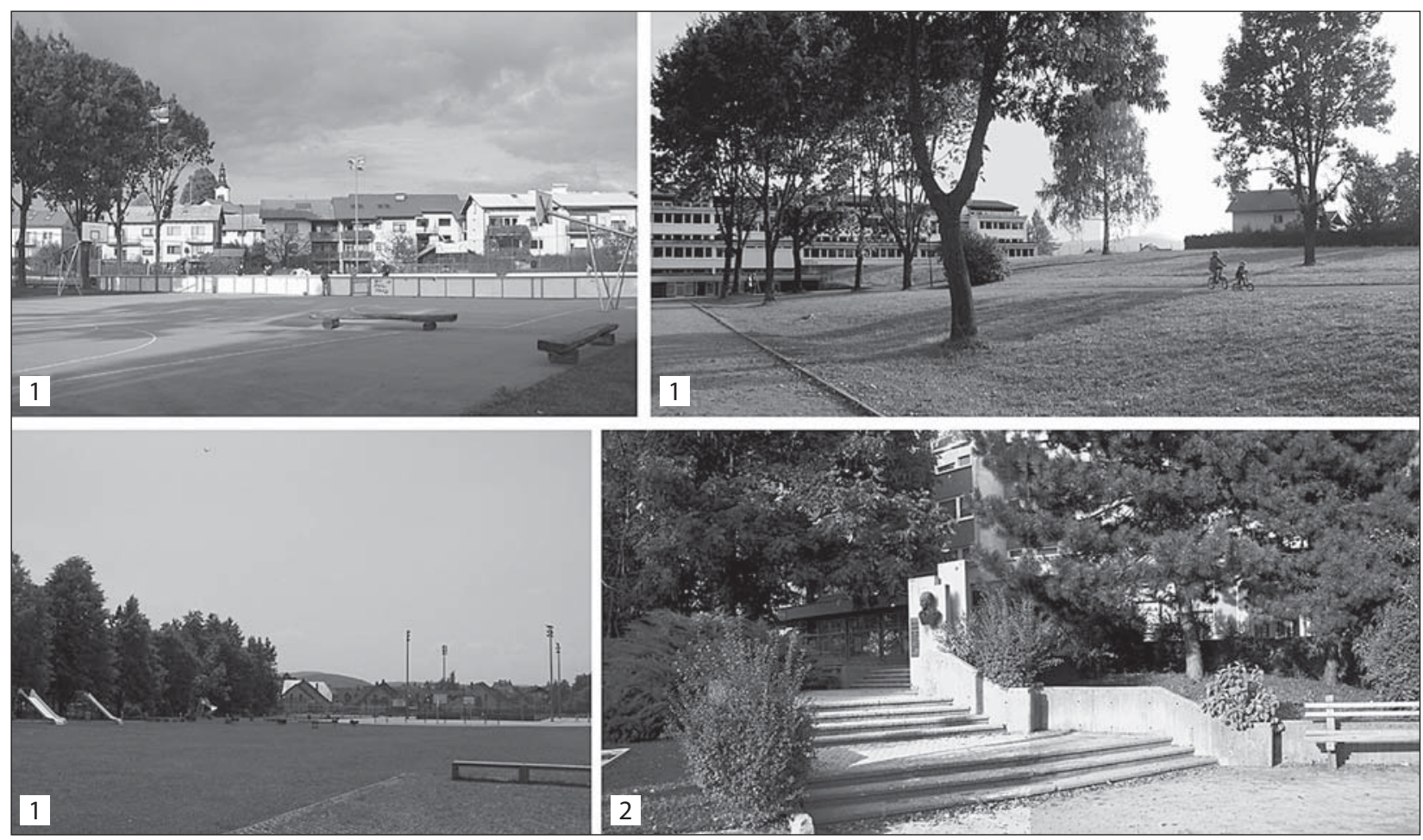

Slika 4: 1 - površine ob šolah, ki vzpodbujajo predvsem aktivno udeležbo in manj pasivno. Klopi se na primer pojavljajo le v neposredni bližini igrišč; 2 - primer ureditve pred objektom javnega značaja, ki jo uporabljajo različne skupine uporabnikov in vzpodbuja vse tri vrste dejavnosti (foto: Klara Sulič). 
vstopa do drugega potujemo le kratek čas. V Grosupljem vse vstope zaznamujejo obrtno-poslovne cone in velika distribucijska parkirišča avtomobilov. Območja so slabo strukturirana in vidno izpostavljena, zato je urejanje prostora in vpadnic z zelenimi členitvenimi potezami na teh mestih nujno. Druga pomanjkljivost je vsebinsko in fizično neizoblikovan center mesta. V Grosupljem lahko zelene površine v tem primeru izboljšajo predvsem strukturo prostora, ki mora dobiti enotno in od ostalih delov mesta različno podobo. Arhitekturnih sprememb je načrtovanih veliko in prostorska stiska je precejšnja. S tega vidika morajo ureditve odprtega prostora (zelenice, ploščadi, zasaditev, klopi ipd.) pred načrtovanimi novimi objekti javnega značaja nujno dobiti širšo družbenopovezovalno vlogo in ne le estetske. Z vidika pešca bo prek takih površin center mesta, $v$ katerem so skoncentrirane oskrbne dejavnosti, bolj kakovostno in zanimivejše povezan z območji oddiha in rekreacije ter stanovanjskimi območji. Gibanje pešca $v$ mestu bo prijetnejše.

\section{Anketna raziskava}

\subsection{Metoda dela}

Namen krajše anketne raziskave je bil pridobiti informacije o tem, kakšno mnenje imajo prebivalci Grosupljega o urejenosti zelenih površin, kako pogosto jih uporabljajo, katere površine in vsebine pogrešajo in kako bi ocenili podobo mesta. Rezultati ankete so bili kasneje kot dopolnilo $\mathrm{k}$ analizi prostora in pomoč uporabljeni pri oblikovanju koncepta ter usmeritev za urejanje zelenih površin in odprtega prostora v mestu. Glede na prostorske značilnosti mesta, prevladujoč delež enodružinske gradnje med stanovanjskimi območji in velik delež priseljenih so bila med izhodišči za anketo naslednja vprašanja:

- Ali ljudje, ki živijo v enodružinski hiši, enako izražajo potrebo po javnih zelenih površinah kot prebivalci večstanovanjskih objektov?

- Katere površine si želi dopolniti ena in druga skupina uporabnikov?

- Ali se razlike v odnosu do zelenih površin pojavljajo tudi med skupinama priseljencev in domačinov?

Anketa je bila zasnovana tako, da bi bila ob analizi rezultatov mogoča preveritev odnosov med navedenima paroma skupin uporabnikov (prebivalci enodružinskih hiš - večstanovanjskih objektov, priseljeni - domačini). Za priseljene so bili opredeljeni anketiranci, ki živijo v mestu manj kot 15 let. Prav tako so bili kasneje preverjeni odnosi po starostnih skupinah in spolu. Ker je bilo število anketiranih manjše, so lahko rezultati preveritev v glavnem le nakazovali razlike med navedenimi uporabniškimi skupinami, niso pa jih mogli potrditi. V nadaljevanju so zato po uporabniških skupinah predstavljene preveritve, $v$ katerih so te razlike najočitnejše, sicer pa so rezultati podani za anketirane na splošno.

$\mathrm{Na}$ podlagi izhodišč in namenov je bil oblikovan vprašalnik $z$ dvajsetimi vprašanji in podvprašanji. Med njimi so bila vprašana zaprtega tipa, torej z vnaprej podanimi odgovori, ter vprašanja, zasnovana po metodi družbenoprostorskih obrazcev, ob katerih so anketirani odgovore zarisali na zemljevid mesta. Vprašanja so bila vsebinsko razdeljena $\mathrm{v}$ štiri tematske sklope: prepoznavnost in značilnosti mesta kot jih vidijo priseljeni in domačini; podoba mesta, ki zajema tudi nove poselitvene posege; urejenost in potrebnost (kje, koliko) zelenih površin v Grosupljem ter socialno-demografske značilnosti. V nadaljevanju bodo predstavljeni prvi trije sklopi, med njimi prepoznavnost in podoba skupaj. Poleg odgovorov na vprašanja ankete so bili sproti zabeleženi tudi komentarji anketirancev, ki so se nanašali na obravnavano temo.

Anketiranje je potekalo na terenu, na celotnem območju mesta in v prvi polovici leta 2006. Anketirani so bili izbrani naključno ali po metodi tako imenovane snežne kepe, skozi socialno mrežo.

\subsection{Rezultati}

Podoba, prepoznavnost oziroma značilnosti mesta - primerjava med priseljenimi in domačini

Anketirani so ocenjevali podobo in prepoznavnost ter navajali značilnosti mesta na podlagi šestih vprašanj. Med njimi je bilo tudi vprašanje, v katerem so prek fotografij ocenjevali posamezne prizore oziroma ureditve $\mathrm{v}$ mestu.

Ugotovljeno je bilo, da je za vprašane Grosuplje najbolj prepoznavno po prometni ureditvi in dostopnosti mesta. To sta značilnosti, ki sta med 95 navedenimi po pogostnosti pojavljanja najbolj izstopali. Tako priseljeni kot domačini vidijo kot največjo prednost bližino in dobre povezave z Ljubljano. Oboji med najočitnejše značilnosti štejejo tudi neurejene ceste, kolesarske poti in pešpoti. Ob tem so bili s strani priseljenih zabeleženi komentarji, da jim mesto ni ponudilo, kar jim je bilo obljubljeno, to je prijetno, varno in mirno mesto $\mathrm{v}$ zelenju. Med komentarji domačinov se je pojavljalo prepričanje, da se zaradi priseljencev mesto spreminja in da mestna občina, ki jih je sem vabila, ni poskrbela 
za osnovne stvari, kot je urejena infrastruktura. Iz komentarjev lahko sklepamo, da se anketirani $\mathrm{v}$ vlogi pešca $\mathrm{v}$ takem prostoru ne počutijo lagodno in da jih neurejena infrastruktura poti odvrača od tega, da bi se po prostoru gibali peš. V Grosupljem je torej za nadaljnje urejanje odprtega prostora in zelenih površin predpogoj, da se izboljšata prometni sistem in infrastruktura, ki bosta tudi pešcem dajala občutek varnosti in prijetnega prostora. Razlike med priseljenimi in domačini so bile najočitnejše $\mathrm{v}$ tem sklopu vprašanj, vendar niso bile značilne. Zato lahko domnevo o razliki v dojemanju prostora med tema skupinama uporabnikov le delno potrdimo. Razlike med ostalimi skupinami, ki so se preverjale, niso bile značilne.

Preglednica 1: Značilnosti Grosupljega, kot so jih navedli priseljeni, domačini oziroma vsi skupaj. Prikazane so najpogosteje izražene značilnosti.

\begin{tabular}{|l|l|l|}
\hline Priseljeni & Domačini & Vsi skupaj \\
\hline $\begin{array}{l}\text { bližina Ljubljane } \\
\text { (dostopnost, } \\
\text { povezave, } \\
\text { migracije) }\end{array}$ & $\begin{array}{l}\text { neurejene ceste, } \\
\text { kolesarske poti } \\
\text { in pešpoti }\end{array}$ & $\begin{array}{l}\text { neurejene ceste, } \\
\text { kolesarske poti } \\
\text { in pešpoti }\end{array}$ \\
\hline $\begin{array}{l}\text { neurejene ceste, } \\
\text { kolesarske poti in } \\
\text { pešpoti }\end{array}$ & $\begin{array}{l}\text { bližina Ljubljane } \\
\text { (dostopnost, } \\
\text { povezave, migracije) }\end{array}$ & $\begin{array}{l}\text { bližina Ljubljane } \\
\text { (dostopnost, } \\
\text { povezave, } \\
\text { migracije) }\end{array}$ \\
\hline $\begin{array}{l}\text { kazino Kongo } \\
\text { hitra rast in razvoj } \\
\text { (priseljevanje, } \\
\text { novogradnje) }\end{array}$ & $\begin{array}{l}\text { hitra rast in razvoj } \\
\text { (priseljevanje, } \\
\text { novogradnje) }\end{array}$ \\
\hline $\begin{array}{l}\text { naravno okolje in } \\
\text { kmetijska krajina }\end{array}$ & $\begin{array}{l}\text { spalno naselje } \\
\text { Ljubljane }\end{array}$ & $\begin{array}{l}\text { spalno naselje } \\
\text { Ljubljane }\end{array}$ \\
\hline Louis Adamič & $\begin{array}{l}\text { Grosupeljščica } \\
\text { Koščakov hrib } \\
\text { in Grosupeljččica }\end{array}$ \\
\hline
\end{tabular}

V odgovorih o značilnostih mesta se pojavljajo tudi zelene površine. Med najpogosteje izraženimi sta Koščakov hrib in potok Grosupeljščica. Iz zgodovine Grosupljega lahko ugotovimo, da ju prebivalci že več let neformalno uporabljajo kot rekreacijski površini. Neformalno predvsem zato, ker območji nista bili vzdrževani kot rekreacijski površini in ker so ju uporabniki prilagajali svojim potrebam - shojene poti, dostopi do vode ipd. Prostorska analiza je pokazala, da sta to osrednji zeleni površini $v$ mestu. Grosupeljščica je tudi ključni povezovalni element več urejenih zelenih površin $\mathrm{v}$ mestu. S tega vidika je smiseln razmislek o oblikovanju večjega osrednjega parkovnega in rekreacijskega območja mesta. Pri tem gre bolj kot za samo velikost območja za učinkovito strukturno ter vsebinsko povezovanje obstoječih odprtih prostorov (tudi vključitev ureditve pred domom starejših občanov v širši sistem) in zelenih površin, vključno z izboljšanjem kakovosti teh površin. S takim pristopom bi povečali zanimivost in potencialno uporabnost površin za uporabnike na splošno ter tudi oblikovali enega izmed osrednjih elementov podobe mesta. Cilj takega pristopa je tudi ustvariti bolj dinamičen odprti prostor mesta, ki bo ustrezen za družabne stike. V odgovorih anketiranih se namreč pojavlja mnenje, da ima mesto še vedno bolj podeželski značaj in da odprti prostor premalo ustreza prostorom, primernim za druženje.

V smislu podobe mesta lahko iz odgovorov razberemo le splošno ugotovitev, da anketirani prepoznajo prostore, ki se jim zdijo najprivlačnejši, kot slabo urejene (Koščakov drevored, park ob tržnici, območje Grosupeljščice) in da prepoznajo glavno mestno vpadnico ter vstope $\mathrm{v}$ mesto kot manj privlačne in tudi manj urejene. Ugotovitve se tako delno skladajo z ugotovitvami prostorske analize.

Potrebe po zelenih površinah - primerjava med potrebami prebivalcev enodružinskih hiš in potrebami prebivalcev večstanovanjskih objektov

Potrebe po zelenih površinah, zadovoljstvo z ureditvami in s količino teh površin, pogostnost obiskovanja, območja obiskovanja in predloge o umestitvi posameznih tipov zelenih površin so anketirani ocenjevali $\mathrm{v}$ sklopu petih vprašanj. V nadaljevanju so predstavljene ugotovitve o potrebah, zadovoljstvu in predlogih. Ker odgovori $\mathrm{v}$ anketnih raziskavah izražajo predstave, želje in pričakovanja uporabnikov prostora ter se lahko tudi hitro spreminjajo, je bil ta sklop vprašanj zastavljen dvojno. Uvodno vprašanje je preverjalo mnenje anketirancev o pomembnosti posameznih tipov zelenih površin v mestih na splošno, vprašanja $v$ nadaljevanju pa so se nanašala na Grosuplje. Anketiranci lahko na primer menijo, da so parki $\mathrm{v}$ mestih zelo pomembni, vendar bi za Grosuplje rekli, da parkov ne potrebuje. $V$ tem primeru bi se sklepalo, da površine v Grosupljem, take kot so, že zadovoljujejo potrebe anketiranega. V tem sklopu vprašanj se je za zapis odgovorov uporabljal zemljevid mesta.

Iz odgovorov lahko ugotovimo, da se zdijo anketiranim zelene površine in odprti prostori Grosupljega v splošnem slabo urejeni. Med posameznimi tipi zelenih in odprtih površin so bile izpostavljene ureditve ob potokih, kolesarske poti in pešpoti $\mathrm{v}$ mestu, parkovne površine ter rekreacijske poti v naravi. Med komentarji je bilo zabeleženo nestrinjanje s pozidavo brežin in $\mathrm{z}$ onesnaževanjem Grosupeljščice. S prostorsko analizo se ta mnenja lahko potrdi. Ker je treba pri urejanju obvodnega prostora $\mathrm{v}$ mestu misliti tudi na poplavno varnost Grosupljega, pomeni tak način širitve poselitve manjše možnosti za uvajanje javnih vsebin, urejanje dostopov do vode, oblikovanje rekreacijsko-parkovne ureditve vzdolž potoka in nazadnje tudi zmanjševanje pomena narave v mestu. 
V odgovorih, $v$ katerih so bili na zemljevidu zabeleženi predlogi anketiranih o tem, kam v mestu naj bi se umestile nove zelene površine, je prostor Grosupeljščice izstopal kot območje parkov in rekreacije. Predlogi naj bi temeljili na oceni anketiranca o potrebnosti površin $\mathrm{v}$ določenem delu mesta, ne glede na to, kje sam biva. Kljub temu je bilo mogoče opaziti, da je večina najprej razmišljala o svojem neposrednem bivalnem okolju in šele nato o mestu kot celoti. Predlogi anketirancev so bili kasneje upoštevani pri analizi primanjkljaja zelenih površin kot dodatna utemeljitev in potrditev pri ugotovitvah analize prostora. Zaradi navedenih subjektivnosti in značilnosti odgovorov ti seveda niso bili neposredno preneseni v nadaljnje delo, temveč kritično povzeti. Primerjava med posameznimi skupinami uporabnikov v sklopu ureditev in predlogov ni pokazala značilnih razlik.

Poleg ustreznosti ureditve zelenih površin in odprtih prostorov so anketirani ocenjevali tudi (ne)zadostno količino teh površin. Med najpogostejšimi odgovori, da določene površine primanjkuje, so bile ureditve ob potokih, kolesarske poti in pešpoti ter parkovne površine. Primerjava med prebivalci enodružinskih hiš in večstanovanjskih objektov nakazuje razlike, ki pa spet niso statistično značilne. Potrdimo lahko domnevo, da javne zelene površine tako kot anketiranci, ki živijo v večstanovanjskih objektih, pogrešajo tudi anketiranci, ki živijo v enodružinskih hišah, oziroma da po njih izkazujejo potrebo. Iz primerjave lahko povzamemo, da po mnenju prvih bolj primanjkuje zelenih površin, kot so parki, cvetlične gredice, poljavne površine ipd. To so površine, na katerih se lahko anketirani udejstvujejo aktivno ali pasivno, na katerih lahko najdejo zasebnost ali družbo, in površine, ki zadovoljijo njihovo potrebo po estetskem. Mnogi so kot komentar navedli, da cvetlične gredice izboljšujejo podobo mesta. Po mnenju anketirancev, ki živijo v enodružinskih hišah, primanjkuje $\mathrm{v}$ mestu in na njegovem obrobju

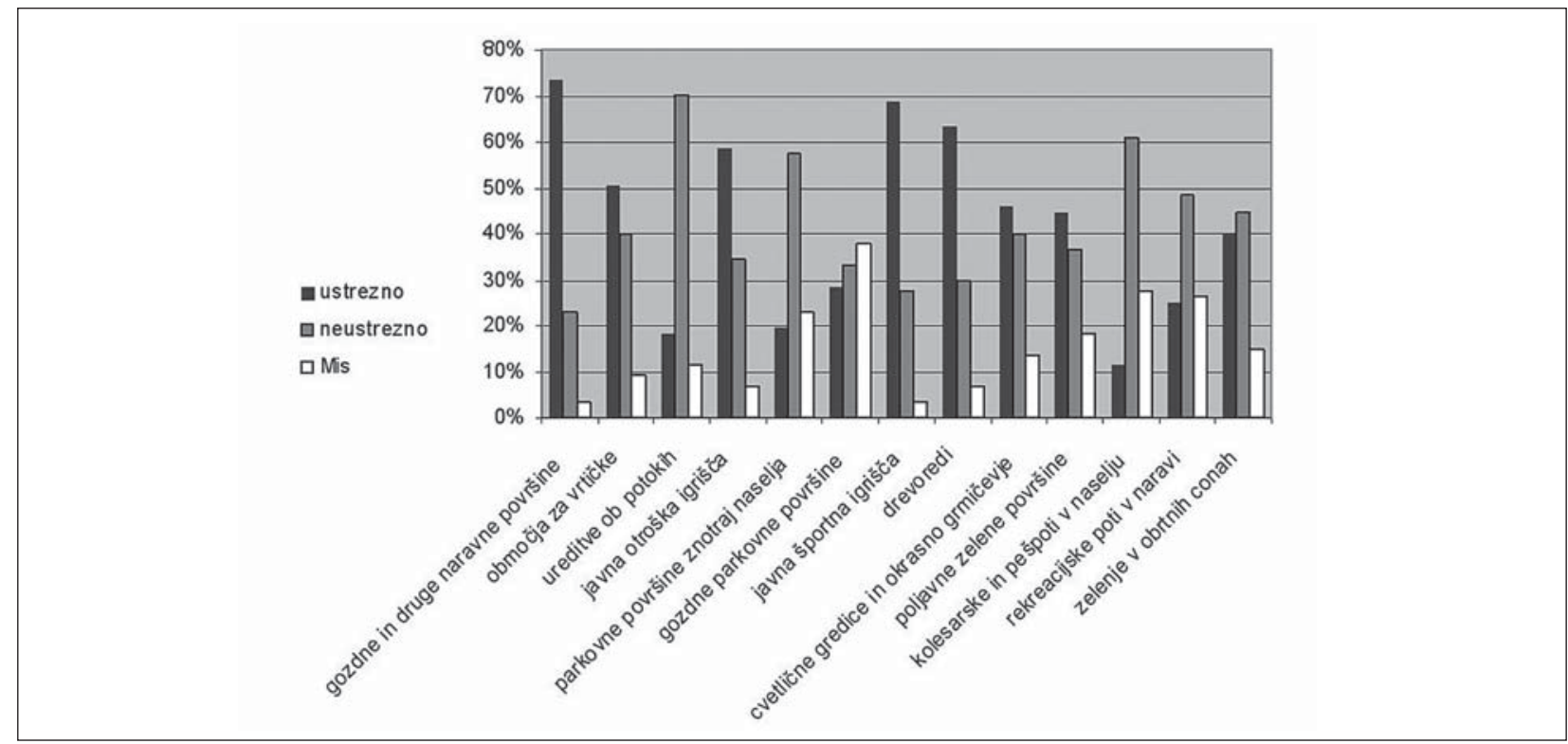

Slika 5: Mnenja anketirancev o ustrezni urejenosti različnih tipov zelenih in odprtih površin. (Ne)ustreznost je prikazana v deležih znotraj posameznega tipa in je primerljiva z deleži znotraj ostalih tipov.

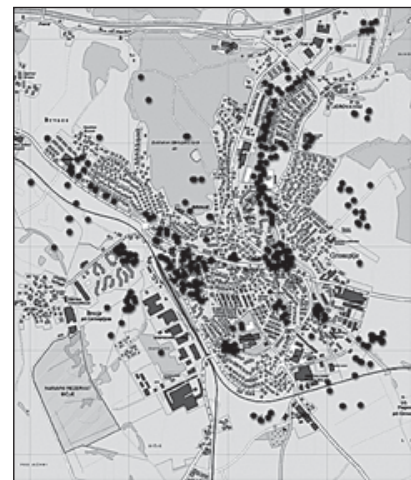

parki

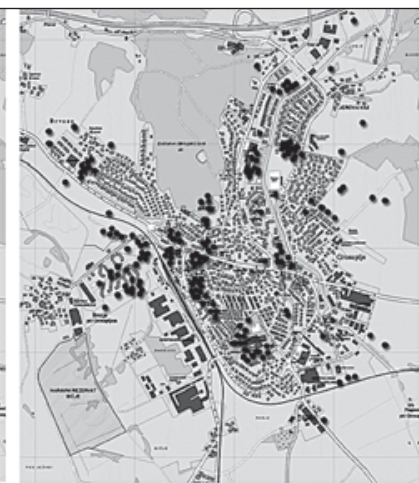

otroška igrišča

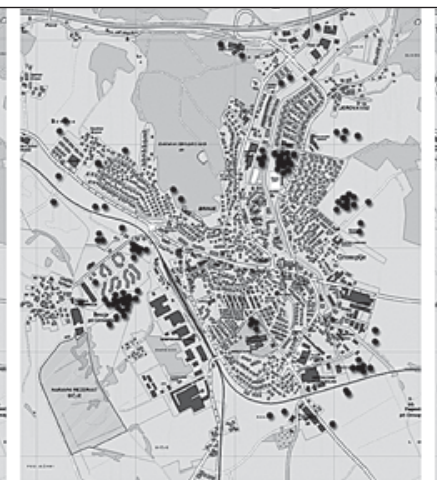

športna igrišča

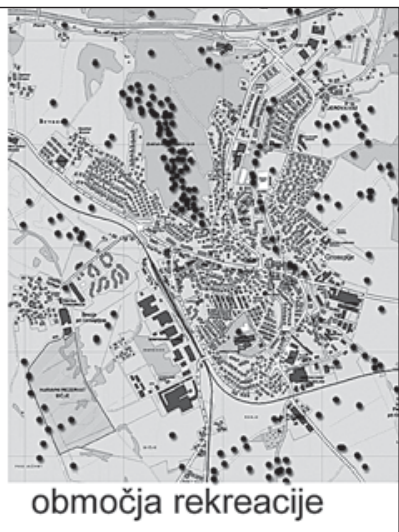

območja rekreacije

Slika 6: Predlogi anketirancev o umestitvi posameznih tipov zelenih površin. 
Preglednica 2: Izraženost potreb po zelenih površinah glede na tip objekta, v katerem živijo anketirani.

\begin{tabular}{|c|c|c|}
\hline $\begin{array}{l}\text { Enodružinska } \\
\text { hiša }\end{array}$ & $\begin{array}{l}\text { Večstanovanjski } \\
\text { objekt }\end{array}$ & Vsi skupaj \\
\hline $\begin{array}{l}\text { kolesarske poti } \\
\text { in pešpoti v } \\
\text { naselju }\end{array}$ & $\begin{array}{l}\text { parkovne površine } \\
\text { znotraj naselja }\end{array}$ & $\begin{array}{l}\text { kolesarske poti in } \\
\text { pešpoti v naselju }\end{array}$ \\
\hline $\begin{array}{l}\text { ureditve ob } \\
\text { potokih }\end{array}$ & $\begin{array}{l}\text { kolesarske poti in } \\
\text { pešpoti v naselju }\end{array}$ & $\begin{array}{l}\text { parkovne površine } \\
\text { znotraj naselja }\end{array}$ \\
\hline $\begin{array}{l}\text { rekreacijske poti } \\
\text { v naravi }\end{array}$ & $\begin{array}{l}\text { cvetlične gredice in } \\
\text { okrasno grmičevje } \\
\text { ob cestah, v križiščih } \\
\text { in pred posameznimi } \\
\text { objekti }\end{array}$ & ureditve ob potokih \\
\hline $\begin{array}{l}\text { parkovne } \\
\text { površine znotraj } \\
\text { naselja }\end{array}$ & $\begin{array}{l}\text { ureditve ob } \\
\text { potokih }\end{array}$ & $\begin{array}{l}\text { rekreacijske poti v } \\
\text { naravi }\end{array}$ \\
\hline $\begin{array}{l}\text { gozdne } \\
\text { parkovne } \\
\text { površine }\end{array}$ & $\begin{array}{l}\text { poljavne zelene } \\
\text { površine v } \\
\text { stanovanjskih } \\
\text { območjih }\end{array}$ & $\begin{array}{l}\text { cvetlične gredice in } \\
\text { okrasno grmičevje } \\
\text { ob cestah, v } \\
\text { križiščih in pred } \\
\text { posameznimi objekti }\end{array}$ \\
\hline
\end{tabular}

predvsem območij za rekreacijo, na katerih bi lahko zadovoljili tiste potrebe, ki jim jih zasebni vrt ne omogoča. Glede pozornosti pri oblikovanju ter vsebini odprtega prostora in zelenih površin lahko iz navedenih ugotovitev sklenemo, da pripisujeta obe skupini anketirancev temu skoraj enako težo. Domneva, da se potrebe prebivalcev enodružinskih hiš in večstanovanjskih objektov razlikujejo, je lahko s to raziskavo delno potrjena in nakazuje, da je celostni pristop pri načrtovanju in urejanju zelenih površin $v$ takem mestu nujen. Razlike med uporabniškimi skupinami glede na starost so bile $\mathrm{v}$ tem sklopu le nakazane, ne pa tudi značilne. Navezujejo se na to, ali posamezna skupina čuti pomanjkanje bolj rekreacijskih površin (srednje starosti) ali drugih oblikovanih, kot so parki, ureditve ob vodotokih, otroška igrišča ipd. (mladi do 25 let in starejši).

\section{Uporabnost raziskave}

$\mathrm{V}$ anketo je bil vključen razmeroma majhen vzorec (pod 100), ki je premajhen, da bi bil statistično reprezentativen in da bi bili lahko pridobljeni podatki posplošeni na vso populacijo mesta. Kot je bilo nakazano v zgornjih poglavjih, zaradi tega tudi ni bila mogoča zares ustrezna primerjava rezltatov med vnaprej določenimi uporabniškimi skupinami (prebivalci enodružinskih hiš - večstanovanjskih objektov, priseljeni - domačini). Razlike po spolu niso bile značilne, razlike po starosti pa so bile le nakazane. Rezultati so tako predstavljeni v najznačilnejših in najbolj ključnih točkah raziskave.

Celotna raziskava je lahko kljub nekaterim pomanjkljivostim predvsem anketnega dela in s poglobljeno prostorsko analizo ustrezna podlaga za obsežnejšo raziskavo, ki bi lahko podala konkretnejše rezultate. Uporabna so izhodiščna razmišljanja in domneve, ki se lahko v nadaljevanju razvijejo v podrobnejšo hipotezo, in prav tako sta uporabni metodi dela. V delu prostorske analize bi bilo na primer smiselno metodo nadgraditi po vzoru vedenjskih zemljevidov B. Goličnik (2006) ali drugih podobnih. Ti zahtevajo tudi temeljitejše priprave in izvedbo.

\section{Sklep}

Cilj raziskave, ki je vključevala anketo in prostorsko analizo, je bil podati predlog koncepta zelenih in odprtih površin Grosupljega ter splošne smernice za njihovo urejanje. S pomočjo pridobljenih rezultatov so bili ugotovljeni posamezni problemi zelenih površin, odprtega prostora in podobe Grosupljega, nakazane pa so bile tudi potrebe anketiranih po določenih tipih teh površin. Najprej se mora v mestu urediti varne in prijetne poti za pešce in kolesarje, saj

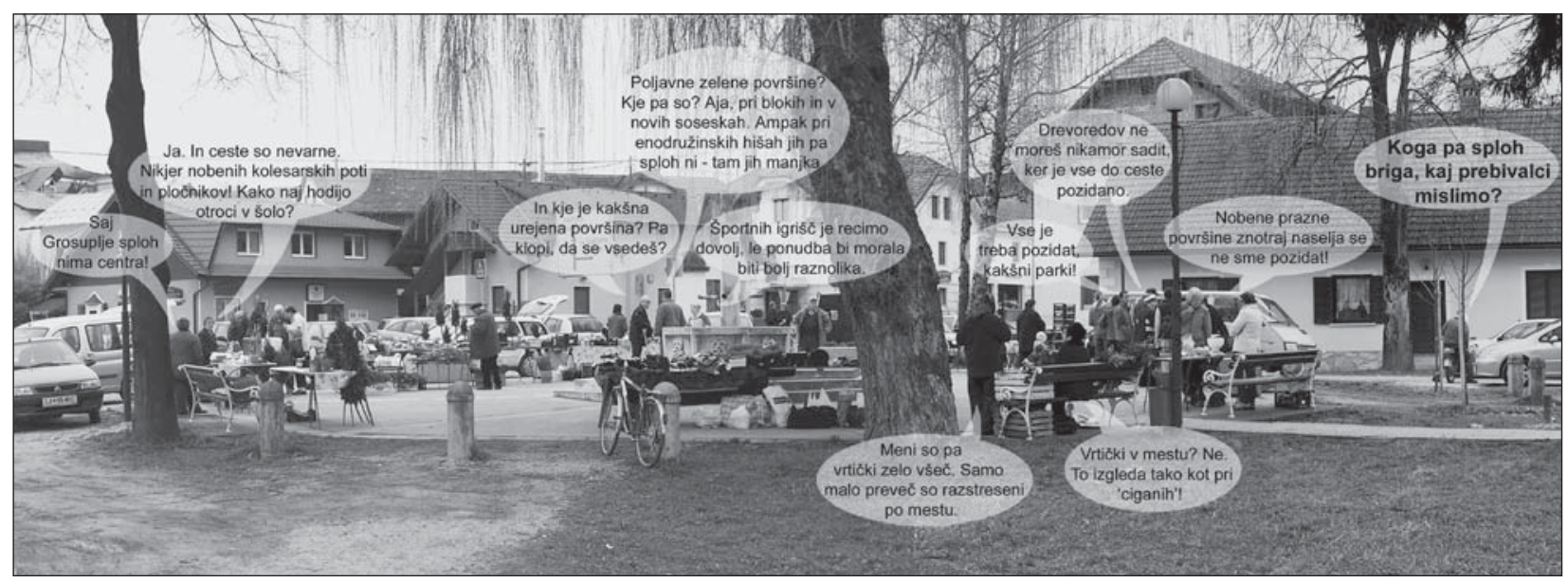

Slika 7: Nekateri izmed značilnih komentarjev anketiranih, prikazani v stripu (foto: Klara Sulič). 
je bilo v obeh analizah ugotovljeno, da je to problem, ki mora biti rešen, da se lahko začne nadgradnjo mestnih zelenih površin. Te bo treba $\mathrm{v}$ prihodnosti količinsko dopolniti, in sicer z ureditvijo novih poljavnih in javnih zelenih površin ter parkovnih ureditev ob stanovanjskih območjih na mestnem obrobju. Vsebina naj bo določena glede na potrebe, ocenjene po gostoti in številu prebivalcev v določenem območju ter glede na možnosti dostopa do drugih podobnih površin v bližnji okolici. Na podlagi ugotovitve, da sta $\mathrm{v}$ odprtem prostoru in mestnih zelenih površinah problematična kakovost ureditve in vzdrževanje, je treba te elemente izboljšati. Pozornost naj se posebej nameni ustrezni dopolnitvi urbane opreme. Obstoječe površine, ki so prepoznane kot javne, vendar imajo časovno omejen dostop, naj ostajajo še naprej ključne osrednje zelene površine. Pri tem naj se v okviru količinske dopolnitve mestnih zelenih površin nekatere izmed vsebin (otroška in športna igrišča) vključuje tudi v izbrana nova območja. Rekreacijske površine v zaledju naj se dopolnjuje v smislu urejanja poti, počivališč in informacijske infrastrukture. Za oblikovanje kakovostnejše podobe mesta pa naj se na podlagi analize prostora in delno rezultatov ankete predlaga zavestno oblikovanje centra, mestnih vpadnic in vstopov. Urejanje glavnih vpadnic in centra mora biti celostno. Za oblikovanje naj se uporablja drevnino za drevorede in druge členitvene vegetacijske pasove, ki bodo izboljšali strukturo prostora tudi pri vstopih. Te danes določajo površine obrtnih con. $\mathrm{V}$ osrednjem delu, kjer naj bi se izoblikoval center mesta, so danes načrtovane nekatere arhitekturne spremembe, ki bodo pomembno vplivale na podobo tega območja. Predlaga se, da so krajinske ureditve ob novih objektih hkrati del uličnega prostora, ki pridobijo poleg estetske in reprezentativne še pomembno družbenopovezovalno vlogo. V Grosupljem se morajo torej nadgraditi možnosti, ki jih trenutno ponujajo odprti prostor in zelene površine. Ustvariti je treba kakovostno urejene javne zelene površine in ob tem izkoristi prednosti umeščenosti mesta $\mathrm{v}$ krajinsko zanimiv prostor. Mestne zelene površine naj se z varnimi povezavami poveže z zaledjem, s čimer bi bil sklenjen doživljajski krog, ki bo uporabnika prostora na razmeroma majhnem območju popeljal čez zelo raznolike vsebine in tipe zelenih površin. Te mu bodo nudile možnosti izbire za dejavnosti in večjo kakovost bivanja.

$\mathrm{V}$ dveh letih od začetka raziskave se je stanje mestnih zelenih površin že nekoliko spremenilo. V prostor so bili dodani novi elementi urbane opreme. Najpomembnejše med njimi so klopi in z bežnim opazovanjem lahko ugotovimo, da se na posameznih površinah zdaj zadržuje nekoliko več ljudi. Minimalni posegi lahko torej na podlagi prepoznanih problemov že izboljšajo stanje in kakovost prostora.
Tako kot Grosuplje imajo tudi ostala podobna manjša urbana naselja $z$ bogatim krajinskim zaledjem pomembno prednost. Če razmišljamo o fizičnih okvirih, sta zaradi manjšega poselitvenega prostora analizi stanja in uspešnosti obstoječih zelenih površin ter potreb prebivalcev po takih površinah bolj obvladljivi in lažje izvedljivi. Stroka in mestne službe naj bi se praviloma med seboj tudi lažje povezovale. Ob dobri interpretaciji potreb in želja, sodelovanju in načrtovanju pomeni oboje lažja izhodišča in dobre možnosti za učinkovito ustvarjanje kakovostnega bivalnega okolja.

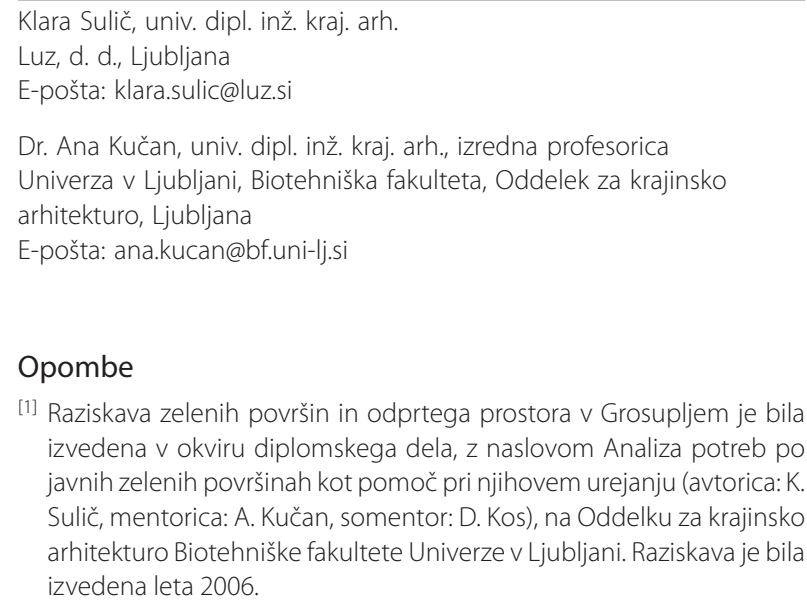
izvedena $v$ okviru diplomskega dela, z naslovom Analiza potreb po javnih zelenih površinah kot pomoč pri njihovem urejanju (avtorica: K. Sulič, mentorica: A. Kučan, somentor: D. Kos), na Oddelku za krajinsko arhitekturo Biotehniške fakultete Univerze v Ljubljani. Raziskava je bila izvedena leta 2006

\section{Viri in literatura}

Dimitrovska Andrews, K., in Repič Vogelnik, K. (1995) Urbanistični kriteriij, normativi in standardi za prostorsko planiranje in urbanistično načrtovanje v Republiki Sloveniji: poročilo o delu v letih 1993 in 1994. Ljubljana, Urbanistični inštitut Republike Slovenije.

Doležal, M. (1991) Pregled zelenih površin in možnost njihove povezave $v$ sistem na ožjem območju mesta Ljubljane. Diplomsko delo. Ljubljana, Biotehniška fakulteta, Oddelek za krajinsko arhitekturo.

Francis, M. (2003) Urban open space: designing for user needs. Washington DC, Island press.

Goličnik, B. (2006) Vedenjski zemljevidi ljubljanskih trgov in parkov: Novi izzivi in pogledi na načrtovanje in urejanje prostora. Ljubljana, Urbani izziv publikacije.

Goličnik, B. (2008) ATP javnih prostorov, v: Simoneti, M., in Marinček, P. (ur.) Odprt javni prostor: načrtovanje, upravljanje, vzdrževanje, str. 40-45. Ljubljana, Društvo krajinskih arhitektov Slovenije.

Goličnik, B., in Šuklje Erjavec, I. (2006) Potrebe, navade in pričakovanja prebivalcev v stanovanjskih krajinah, v: Simoneti, M., in Gazvoda, D. (ur.) Stanovaniske krajine: trendi, perspektive, str. 34-37. Ljubljana, Biotehniška fakulteta, Oddelek za krajinsko arhitekturo.

Marcus, C. C., in Francis, C. (1998) People Places. New York, John Wiley \& Sons, inc.

Polič, M. (1996) Mesto, javni prostor in ljudje, v: Hudoklin, J. (ur.) Urejanje odprtega prostora $v$ urbanem okolju. Zbornik letnega strokovnega srečanja Društva krajinskih arhitektov Slovenije, str. 36-40. Ljubljana, Društvo krajinskih arhitektov Slovenije.

Polič, M. (2000) Izkušnja narave v mestu, v: Marinček, P., Matjašec, D., in Simoneti, M. (ur.) Narava v mestu. Med načrtovanim in spontanim, str. 9-14. Ljubljana, Društvo krajinskih arhitektov Slovenije. 